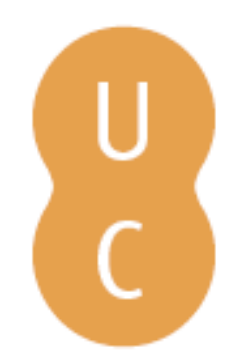

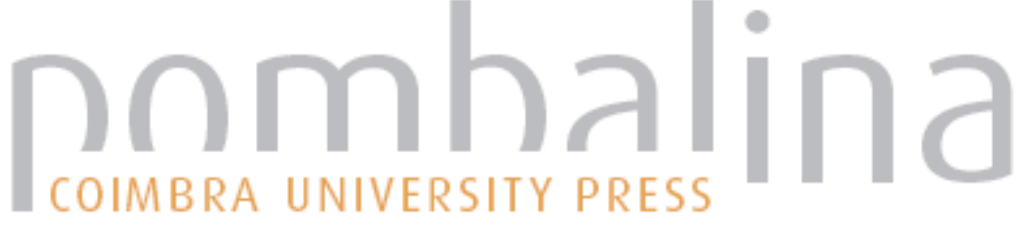

\section{Portugal nos Jogos Olímpicos: breve resenha}
Autor(es):
Maia, Fernando
Publicado por: Imprensa da Universidade de Coimbra
URL persistente:
URI:http://hdl.handle.net/10316.2/38378
DOI:
DOI:http://dx.doi.org/10.14195/978-989-26-0371-1

Accessed : $\quad$ 26-Apr-2023 01:12:18

A navegação consulta e descarregamento dos títulos inseridos nas Bibliotecas Digitais UC Digitalis, UC Pombalina e UC Impactum, pressupõem a aceitação plena e sem reservas dos Termos e Condições de Uso destas Bibliotecas Digitais, disponíveis em https://digitalis.uc.pt/pt-pt/termos.

Conforme exposto nos referidos Termos e Condições de Uso, o descarregamento de títulos de acesso restrito requer uma licença válida de autorização devendo o utilizador aceder ao(s) documento(s) a partir de um endereço de IP da instituição detentora da supramencionada licença.

Ao utilizador é apenas permitido o descarregamento para uso pessoal, pelo que o emprego do(s) título(s) descarregado(s) para outro fim, designadamente comercial, carece de autorização do respetivo autor ou editor da obra.

Na medida em que todas as obras da UC Digitalis se encontram protegidas pelo Código do Direito de Autor e Direitos Conexos e demais legislação aplicável, toda a cópia, parcial ou total, deste documento, nos casos em que é legalmente admitida, deverá conter ou fazer-se acompanhar por este aviso.

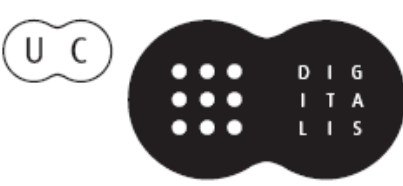


FRANCISCO DE OLIVEIRA

Coordenação

Ospírito Olímpico

no

novo milénio 
PORTUGAL NOS JOGOS OLÍMPICOS

BREVE RESENHA

Fernando Maia Universidade de Coimbra

É consensual a ideia de que os Jogos Olímpicos constituem, na actualidade, um elemento central e estrutural do desenvolvimento da cultura desportiva moderna. A sua renovação, operada em finais do século passado, constituiu a expressão institucional do Olimpismo como movimento social e cultural. Foi ele que tornou inevitável a universalidade do desporto, perante tendências dominantes de uma sociedade em permanente mutação quer pela internacionalização das ideias e das práticas sociais, quer pelas alterações políticas e económicas ocorridas.

É no contexto da mediatização (fruto do avanço técnico do nosso tempo) e da universalidade dos grandes acontecimentos desportivos que os Jogos Olímpicos podem ser considerados como a maior manifestação desportiva da actualidade. Com o seu impacto, têm marcado a sociedade, pelo que os podemos elevar à categoria do maior espectáculo dos tempos modernos.

\section{A participação portuguesa}

Quando, em finais do séc. XIX, Pierre de Coubertin se apaixona pela ideia de fazer reviver os Jogos Olímpicos da Antiguidade e transformálos num grande acontecimento desportivo da Era Moderna, em Portugal vivia- se um período de instabilidade política que levaria ao regicídio 
ocorrido em 1908 e, logo após, à deposição do regime monárquico e à implantação da República.

Por isso, não é estranho que os primeiros Jogos Olímpicos da Era Moderna realizados em 1896, na cidade de Atenas, fossem ignorados em Portugal. A comprová-lo, está o facto de a imprensa diária e desportiva da época não fazerem qualquer referência ao acontecimento o que pode significar que seriam do seu desconhecimento ou que não Ihe suscitavam interesse.

A II Olimpíada realizada em 1900, em Paris, coincidiu, conforme deliberação anterior, com a Exposição Internacional que teve lugar na capital francesa.

Ofuscados pela realização do certame internacional, os Jogos não assumiram a importância e não obtiveram o impacto pretendido, acontecendo mesmo que os próprios franceses se alheassem da sua realização. Mesmo a imprensa internacional preocupou-se mais com a divulgação dos eventos que iam acontecendo na Feira Internacional, do que, propriamente, com os acontecimentos desportivos relacionados com o decurso dos Jogos Olímpicos.

Em Portugal, à semelhança do que havia acontecido relativamente à I Olimpíada, na imprensa nacional não se encontra qualquer referência aos Jogos Olímpicos de Paris.

$\mathrm{Na}$ senda da informação desportiva que se propunha, a revista O Tiro CiviK'), no seu n. ${ }^{\circ} 187$, de I de Junho de 1900 , notícia a realização de Concursos Internacionais de Esgrima a realizar de 14 de Maio a I de Junho no Grande Salão de Festas da Exposição de Paris. Se atentarmos nas datas, verificamos que elas coincidem com as da realização dos Jogos Olímpicos e também estes têm início com uma prova de esgrima, actividade muito em voga no início do século.

Nestes concursos participaram os nossos compatriotas Sebastião 214 Herédia e António Martins. Quanto ao comportamento desportivo destes nossos representantes, é omissa a informação de que dispomos, apesar de terem sido atribuídos os números respeitantes à sua partici-

O Revista semanal criada a 7 de Março de 1895, que se destinava a dar notícias e informações respeitantes a certos desportos, dos quais destacamos o tiro, a esgrima, a ginástica e a caça. 
pação, bem como haver conhecimento de terem sido sorteados os mestres de armas com que se haviam de defrontar. Contudo, não há qualquer referência a resultados, pelo que se poderá presumir que a nossa primeira participação se saldou por uma falta de comparência, pois que há notícia de os seus adversários terem passado à eliminatória seguinte.

Se bem que este episódio, pelo tempo em que ocorre, revele que a nossa participação pode ter acontecido antes da própria adesão de Portugal ao movimento olímpico, (o que só vem a acontecer em 1906), ele não deixará, por certo, de ter contribuído, para um processo que levaria à criação da Sociedade Promotora da Educação Física Nacional, em 1909 e, Posteriormente, à formação do Comité Olímpico Português, a 30 de Abril de 1912, portanto, alguns meses antes da realização da V Olimpíada. Nesta, a nossa representação assume, pela primeira vez, o carácter de representação oficial.

Perante os factos aludidos e não havendo qualquer referência à nossa participação nos Jogos que se realizaram em 1904 e 1908, podemos concluir que, oficialmente, a primeira participação portuguesa nos Jogos Olímpicos remonta à celebração da V Olimpíada, realizada de 5 de Maio a 22 de Junho de 1912, na cidade de Estocolmo.

Com uma presença modesta, traduzindo com fidelidade a incipiente organização do desporto nacional, a representação portuguesa foi confiada a 6 atletas: Fernando Correia, António Stromp, Armando Cortesão (que, no futuro, viria a ser um ilustre e insigne historiador), Francisco Lázaro, Armando Pereira e Joaquim Vital que viriam a participar em 3 modalidades: Esgrima (especialidade de sabre), Atletismo e Luta Greco-Romana. A viagem destes atletas rumo à Suécia, realizou-se a bordo do navio Astúrias, pertencente à Marinha Real Inglesa.

Em consequência de resultados anteriormente obtidos numa Maratona realizada em Lisboa ( $2 \mathrm{~h} 52 \mathrm{~m}$ 8s), a comitiva portuguesa depositava as maiores e fundadas esperanças numa boa prestação de Francisco Lázaro. Talvez por isso mesmo, lhe tivesse sido concedida a honra de porta- bandeira na cerimónia inaugural. Mas a realidade foi bem adversa. Quando participava na prova da maratona, à passagem do kilómetro 30, aquele atleta veio a desfalecer, acabando mesmo por 
falecer no dia seguinte. Terá sido o episódio mais dramático da nossa participação nos Jogos Olímpicos e, por certo, aquele que a imprensa considerou mais sensacionalista como acontecimento mediático da representação portuguesa, já que, nas restantes modalidades, o nosso desempenho se fixou, de forma modesta nas eliminatórias que dão acesso às finais.

Lançadas as bases para um participação efectiva no Movimento Olímpico, a partir desta Olimpíada, a presença portuguesa passaria a ser uma constante.

Com representações mais ou menos numerosas, expressando a realidade da organização do desporto nacional, Portugal ir-se-ia mantendo fiel à organização. Cultivava-se o Ideal Olímpico e através dele procurava-se vivificar o simbolismo de uma das mais ricas manifestações das actividades físico- desportivas e culturais do nosso tempo.

Contudo, as Olimpíadas seguintes (1916) não se realizaram. Vicissitudes de ordem política ocasionaram um conflito internacional de grandes proporções - a la Grande Guerra - que envolveu vários países europeus, o que não permitiu a realização dos Jogos de 1916, contrariando os preceitos da Antiguidade em que era declarada a "Trégua Olímpica" durante o tempo dos Jogos.

Assim, ter-se-ia de esperar mais quatro anos, por 1920, para, de novo, podermos assistir a uma nova Olimpíada, desta vez realizada em Antuérpia.

As convulsões sociais que se viviam no nosso País, expressas pelo anarquismo político-constitucional, determinavam limitações orçamentais importantes que impediam grandes gastos económicos, eventualmente considerados como supérfluos. Deste modo, a Antuérpia, apenas foi possível a deslocação de praticantes de esgrima e tiro, em missão custeada pelo Ministério da Guerra. A representação portuguesa foi composta por dez atletas, que representaram o País nas modalidades referidas. Apesar do reduzido número de participantes, a representação não deslustrou. A equipa de Esgrima, na especialidade de espada, conseguiu um $4 .^{\circ}$ lugar, entre I I participantes e, individualmente, na mesma especialidade, obtivemos um $6 .^{\circ}$ lugar. Quanto ao Tiro, na especialidade de tiro de revólver a 30 metros classificámo-nos na 8. ${ }^{\circ}$ posição. 
Depois do fracasso da II Olimpíada, a "cidade Luz" engalanou-se, de novo, para viver a VIII Olimpíada da Era Moderna (1924). Embora as dificuldades políticas, financeiras e sociais continuassem a fazer-se sentir em Portugal, este aspecto foi superado com o recurso a uma subscrição pública para angariação de fundos capazes de suportar a representatividade portuguesa nos Jogos. Por sua vez, a proximidade de França e o recurso ao comboio como meio de transporte, possibilitou a diminuição dos gastos. Daí que a delegação portuguesa fosse composta por 25 pessoas, que vieram a participar em 8 modalidades olímpicas: atletismo, esgrima, equitação, pesos e alteres, natação e ténis. Foi uma representação numerosa, para o tempo. E o que mais se salienta é o facto de ter sido nestes Jogos que Portugal conseguiu, pela primeira vez, um lugar no podium, ao conquistar uma medalha de Bronze na modalidade de Equitação, na especialidade de saltos de obstáculos. A equipa que conseguiu este feito era constituída por um civil - Borges de Almeida - e dois militares - o Tenente Helder Martins e o Capitão Mouzinho de Albuquerque.

Nas restantes modalidades, o comportamento foi modesto. Contudo, o êxito obtido na equitação terá galvanizado a organização portuguesa para, atempadamente, iniciar a preparação da Olimpíada seguinte, que viria a realiza- se em 1928, em Amesterdão.

Foi na senda de um progresso desportivo constituído por um maior cuidado na preparação dos nosso atletas que nos preparámos para participar nesta Olimpíada. Para tal, foi decisivo o papel assumido pelo Comité Olímpico Português, já que, através dele, foi possível a organização de actividades preparatórias e de selecção dos atletas à participação Olímpica.

Também no plano político tudo corria de feição: o Estado havia atribuído uma verba cem mil escudos destinada à participação dos nossos representantes. Contudo, a revolução ocorrida a 28 de Maio de 1928, veio alterar toda a conjuntura, tendo sido retirados os apoios governamentais. Com uma representação composta por 29 pessoas, que se haveriam de distribuir por 8 modalidades, Portugal veio, mais uma vez, a conquistar uma medalha de Bronze, na modalidade de Esgrima especialidade de espada. Mas assinala-se um outro facto digno de registo: a sensação causada pela primeira participação de uma equipa de 
futebol nacional, que atingiu os quartos- de- final, onde foi afastada pelo Egipto.

Os próximos Jogos viriam a ser realizados em 1932, em Los Angeles. A distância, aliada às dificuldades e custos de transporte, bem como os parcos recursos económicos do País e as consequentes restrições impostas pelo Estado Novo, constituíram justificação suficiente para que Portugal apenas se tenha feito representar por 8 elementos, que competiram em 3 modalidades. Foi uma participação sem história, o que, aliás, é fácil de compreender. O melhor que obtivemos foi um $7 .^{\circ}$ lugar no Tiro, na especialidade carabina.

Em 1936, os Jogos Olímpicos realizaram-se em Berlim. Eram tempos de afirmação do regime nazi. De novo na Europa, a comitiva portuguesa passava a ser mais participativa. A nossa representação foi composta por 16 elementos, que se distribuíram por 5 modalidades.

De novo, no hipismo conquistamos uma medalha de Bronze por equipas, numa equipa de que fez parte o Marquês do Funchal.

A II Guerra Mundial veio determinar a suspensão das Olimpíadas de 1940 e 1944. Mais uma vez, os tempos de guerra não foram propícios à sua realização e, por isso mesmo, somente em 1948 voltamos a ver a concretização do espírito Olímpico, nos Jogos que viriam a realizar-se em Londres.

Nestes Jogos, a participação portuguesa foi composta por 45 elementos, que participaram em 7 modalidades olímpicas. Em Portugal, o regime político do Estado Novo preocupava-se mais com os problemas sociais do que propriamente com os desportivos. Não admira, por isso, que o comportamento dos nossos compatriotas apenas tivesse conseguido sobressair na modalidade de vela, na classe de swallow, em que os irmãos Belo (Duarte e Fernando) obtiveram a medalha de prata a primeira do nosso historial Olímpico. Igualmente, no hipismo

218 obtivemos uma medalha de bronze, à semelhança do que tinha acontecido na VIII Olimpíada.

Foi apenas a partir dos Jogos Olímpicos de Helsínquia (1952) que o governo português se começaria a aperceber da verdadeira importância que o desporto viria a assumir no poderio social e cultural estabelecido entre as nações e do papel dinâmico que cabia aos Jogos Olímpicos na sua divulgação. A preparação dos nossos atletas começava a merecer 
algum cuidado em termos de planeamento e organização do treino, o que tornava necessário a afectação de verbas para estágios e a selecção de treinadores especializados.

A própria deslocação para Helsínquia realizou-se num navio fretado para o efeito e o aluguer de lugares a outros passageiros foi uma medida que permitiu reduzir o custo das despesas. A representação portuguesa era composta por 79 atletas que participaram em 10 modalidades (Vela; Esgrima; Remo; Hipismo; Ginástica; Pólo Aquático; Atletismo; Tiro; Pentatlo e Natação). Como resultados mais relevantes, registe-se a conquista de uma medalha de Bronze na Vela, na classe de Stars, e uma actuação relevante, embora sem lugar no podium, na modalidade de Hipismo.

Os Jogos Olímpicos de 1956 deviam ter como cenário a cidade de Melbourne, na Austráliaí2). A representação portuguesa quedou-se pela participação apenas numa modalidade - vela, com 5 representantes. As despesas de deslocação, causadas pela distância e pelo número de dias necessários para a percorrer, foram justificação suficiente para dissuadir os nossos responsáveis. Mesmo assim, e sem termos conseguido um lugar no podium, obtivemos um 4 . $^{\circ}$ Iugar na classe de "Star".

Muitos séculos depois da proibição dos Jogos pelo Imperador Teodósio, na sua cruzada contra o paganismo, em 1960, coube a Roma a organização da XVII Olimpíada. Foi tão importante a sua realização, que quase poderíamos dizer que constituíram um marco decisivo para a sua maior expressão e o seu maior fulgor. Quanto a Portugal, a proximidade geográfica possibilitou uma representação com 62 atletas, que se fizeram representar em I I modalidades. Mas não fosse uma medalha de prata na Vela, na classe Star, e a presença portuguesa teria passado despercebida, já que nas restantes modalidades não passámos das provas de classificativas.

Em 1964, era a vez da realização dos Jogos no País do "sol nascente". A Tóquio, Portugal enviou uma delegação de 20 elementos, para uma participação em 7 modalidades (Vela, Tiro, Atletismo, Natação, Hipismo,

(2) Porém, razões de ordem política que obrigavam a quarentena todos os animais de outros países ali entrados, desde logo impediram a realização das provas de Hipismo. A questão foi ultrapassada pela atitude da Suécia, com a oferta da cidade de Estocolmo para a realização desta disciplina Olímpica, proposta aceite por todos os Comités nacionais. 
Judo e Ginástica). Poderíamos dizer que estes Jogos constituíam uma viragem nos nossos resultados, até então apenas confinados à obtenção de medalhas em actividades que, de alguma forma, estavam ligadas ao meio militar (hipismo e esgrima) e na vela que, embora sendo uma modalidade elitista, tinha muito apoio das Escolas de Vela da Mocidade Portuguesa. Nestes Jogos, o atleta português Manuel de Oliveira superou-se ao vencer uma eliminatória nos 3.000 metros obstáculos e ao obter $04 .^{\circ}$ lugar na final da mesma modalidade. Se bem interpretamos este feito, cremos estar aqui o prenúncio de que algo poderia vir a mudar na prova rainha dos Jogos Olímpicos e, muito particularmente, nas provas de Fundo e Meio-Fundo. Nas restantes provas, e por ironia do destino, mesmo nas modalidades em que Portugal vinha detendo algum prestígio - Vela e Hipismo, não conseguimos qualquer lugar de destaque.

Às Olimpíadas seguintes, realizadas em 1968, na Cidade do México e 1972 em Munique, respectivamente, Portugal apenas se fez representar. Possivelmente, vicissitudes de natureza política interna, a que não será alheio o facto de se achar a braços com uma guerra em três frentes de combate, terão impedido uma melhor representatividade e um maior fulgor à nossa representação. Na Cidade do México, constituíram a nossa representação 23 atletas, que participaram em 6 modalidades. Por sua vez, em Munique, a nossa delegação foi composta por 32 atletas que nos representaram em 8 modalidades (Vela; Atletismo; Tiro; Remo; Luta; Hipismo; Judo; Halterofilia).

E o prenúncio que se anunciava em Tóquio começa a desenhar-se na XXI Olimpíada, realizada em 1976, em Montreal. Portugal, com uma delegação composta por 20 atletas, fazia-se representar em 6 modalidades (Atletismo; Natação; Vela; Luta; Judo e Tiro). Embora com uma representação mais reduzida, pode considerar-se esta uma Olimpíada

220 histórica para o desporto português. A obtenção de duas medalhas de prata (Carlos Lopes nos 10.000 metros e Armando Marques no Tiro especialidade Fosso Olímpico) marcaram bem a nossa presença nestes Jogos.

Mas os Jogos que se seguiram, realizados em 1980, em Moscovo, devolvem a mediocridade à nossa participação. Nestas Olimpíadas, a nossa delegação foi composta por I I atletas que nos representaram em 
6 modalidades (Atletismo Judo; Natação; Ginástica; Halterofilia; Boxe). Sem apoio governamental, em virtude da adesão do nosso país ao boicote decretado pelos Estados Unidos, de retaliação à invasão do Afeganistão pela União Soviética, a representação portuguesa realizou- se a expensas, exclusivamente, do Comité Olímpico de Portugal. Quanto a resultados, apenas a salientar a presença de João Campos na Meia- Final dos 1.500 metros.

Em Los Angeles, em 1984 - Jogos em que a União Soviética e os seus países satélites não participaram, como resposta ao boicote americano da Olimpíada anterior - Portugal, finalmente, conquistou a sua primeira medalha de ouro. Este feito pertenceu a Carlos Lopes que, ao correr a prova da Maratona em $2 \mathrm{~h} 20 \mathrm{~m} 42 \mathrm{~s}$ chegou isolado ao Coliseu. E foi assim que, pela primeira vez na história dos Jogos Olímpicos, a bandeira Portuguesa foi hasteada no mastro principal, ao som dos acordes do Hino Nacional. Foi a concretização do anunciado na XVIII Olimpíada, quando Manuel de Oliveira venceu a eliminatória dos 3.000 metros obstáculos.

Mas o êxito da nossa representação não ficou por aqui: Rosa Mota, na prova feminina da maratona, e António Leitão nos 5.000 metros, obtiveram honrosos 30 lugares, o que Ihes permitiu um lugar no podium e as consequentes medalhas de Bronze.

O resultado conseguido por estes atletas, precisamente na modalidade de Atletismo, conferiu à nossa representação um feito jamais conseguido pelas nossas representações e difícil de igualar.

A Seul (Coreia do Norte), para participar na XXIV Olimpíada, realizada em 1988, Portugal fez-se representar por uma delegação composta por 66 elementos, que participaram em 13 modalidades. Nestes jogos, de novo o atletismo português esteve em foco. A atleta Rosa Mota obteve a medalha de ouro na maratona feminina e Domingos Castro conseguiu o honroso $4 .^{\circ}$ lugar na prova dos 5.000 metros. Pode dizer-se que na modalidade mais importante dos Jogos Olímpicos, Portugal, mostrava- se ao mundo de uma forma aberta e sem complexos ou receios.

A Olimpíada seguinte, em 1992, realizar-se-ia aqui bem perto, em Barcelona Também a nossa representação foi alargada - 99 elementos, que nos representaram em 18 modalidades. Já com as ausências de 
Carlos Lopes e Rosa Mota, as nossas grandes expectativas de êxito iam para o Hóquei em Patins, modalidade na qual Portugal detém prestígio mundial, e que havia sido introduzida nos Jogos Olímpicos, a título experimental. Porém, a representação portuguesa, ao conseguir um modesto $4 .^{\circ}$ lugar, ficou aquém do valor que tradicionalmente lhe é atribuído, não conquistando qualquer lugar no podium. Aliás, toda a representação portuguesa teve uma prestação medíocre, a merecer críticas por parte dos nossos governantes e da imprensa da especialidade.

Na Olimpíada que se seguiu (1996) realizada em Atlanta Portugal fezse representar por 108 elementos, que participaram em 18 modalidades. Quanto a presenças no podium, o maior mérito vai para Fernanda Ribeiro que conquistou a medalha de ouro na corrida dos 10.000 metros femininos. Mas há a registar, igualmente, o excelente comportamento obtido pelos atletas Hugo Rocha e Diogo Barreto, que conquistaram a medalha de bronze na modalidade de vela, na classe de "470", façanha que Portugal não conseguia desde 1960, nos Jogos Olímpicos de Roma.

\section{Conclusão}

Passados mais de 100 anos após a realização dos l.\$s Jogos Olímpicos da Época Moderna, Portugal participou em 20 das 23 Olimpíadas efectivamente realizadas. Nelas competiram 515 atletas, (462 homens e 53 senhoras) que nos representaram em 23 modalidades Olímpicas e que se deslocaram em comitivas mais ou menos numerosas em função da distância de Portugal ao país organizador.

No campo desportivo obtivemos 3 medalhas de ouro, 4 de prata e 8

222 de bronze, bem como conhecemos a tragédia, com a morte de um promissor desportista.

Numa breve análise a estes resultados e tendo em conta a evolução política que vivemos neste século, referimos que durante a "I.a República" e "Estado Novo" os melhores resultados foram obtidos nas modalidades de esgrima, hipismo e vela, através das quais conseguimos 7 medalhas ( 2 de prata e 5 de bronze). 
Já no último quartel deste século obtivemos 8 medalhas com destaque especial para as 6 conseguidas na modalidade de Atletismo (principalmente nas especialidades de Fundo e Meio-Fundo). Foi por ela que a bandeira de Portugal flutuou, bem alto, no mastro principal do podium olímpico. Os resultados alcançados por Carlos Lopes, Rosa Mota e Fernanda Ribeiro, entre outros, são a prova da notoriedade que a Escola Portuguesa de Atletismo assumiu no contexto olímpico.

QUADRO REFERENCIAL DA PARTICIPAÇÃO PORTUGUESA

\begin{tabular}{|c|c|c|c|c|}
\hline ANO & LOCAL & $\begin{array}{c}\mathrm{N} .^{\circ} \text { de } \\
\text { modalidades }\end{array}$ & N. ${ }^{\circ}$ de participantes & MEDALHAS \\
\hline 1900 & Paris & 1 & 2 & \\
\hline 1912 & Estocolmo & 3 & 6 & \\
\hline 1920 & Antuérpia & 2 & 10 & \\
\hline 1924 & Paris & 8 & 25 & Bronze - Hipismo \\
\hline 1928 & Amesterdão & 8 & 29 & Bronze - Esgrima \\
\hline 1932 & Los Angeles & 3 & 8 & \\
\hline 1936 & Berlim & 5 & 16 & Bronze - Hipismo \\
\hline 1948 & Londres & 7 & 45 & $\begin{array}{c}\text { Prata - Vela } \\
\text { Bronze - Hipismo }\end{array}$ \\
\hline 1952 & Helsíquia & 10 & 79 & Bronze - Vela \\
\hline 1956 & Melbourne & $\mathrm{T}$ & 5 & \\
\hline 1960 & Roma & 11 & 69 & Prata - Vela \\
\hline 1964 & Tóquio & 7 & 20 & \\
\hline 1968 & Cidade do México & 6 & 23 & \\
\hline 1972 & Munique & 8 & 32 & \\
\hline 1976 & Montreal & 6 & 20 & $\begin{array}{l}\text { Prata - Atletismo ( } 10.000 \text { metros) } \\
\text { Prata - Tiro (Fosso Olímpico) }\end{array}$ \\
\hline 1980 & Moscovo & 6 & II & \\
\hline 1984 & Los Angeles & 11 & 39 & $\begin{array}{c}\text { Ouro - Atletismo (Maratona) } \\
\text { Bronze - Atletismo (Maratona. Fem.) } \\
\text { Bronze - Atletismo }(5.000 \mathrm{~m} .)\end{array}$ \\
\hline 1988 & Seul & 13 & 66 & Ouro - Atletismo (Maratona. Fem.) \\
\hline 1992 & Barcelona & 18 & 99 & \\
\hline 1996 & Atlanta & 18 & 108 & $\begin{array}{c}\text { Ouro - Atletismo (10.000 m.) } \\
\text { Bronze - Vela }\end{array}$ \\
\hline
\end{tabular}




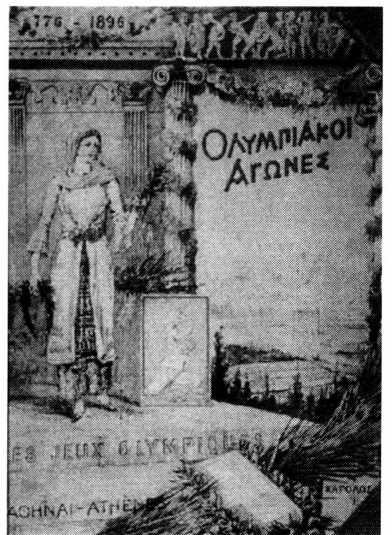

Figura I

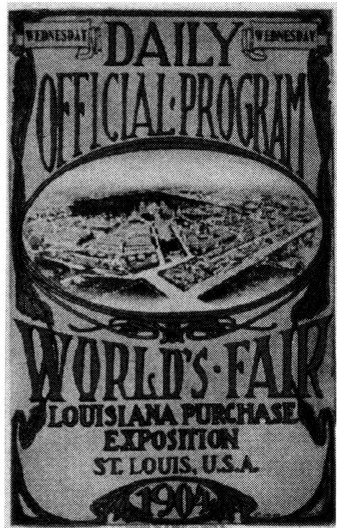

Figura 3

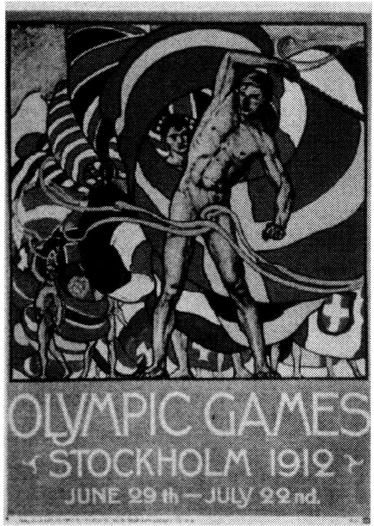

Figura 5

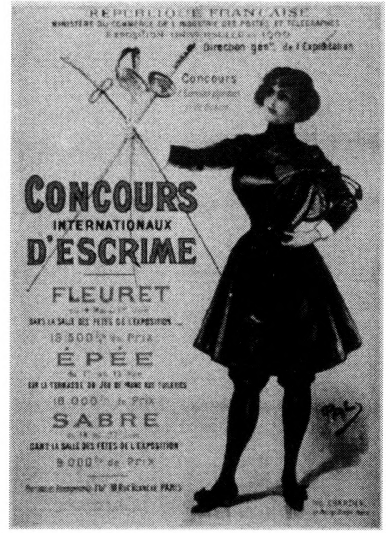

Figura 2

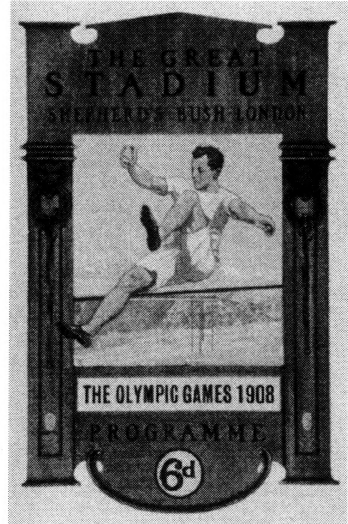

Figura 4

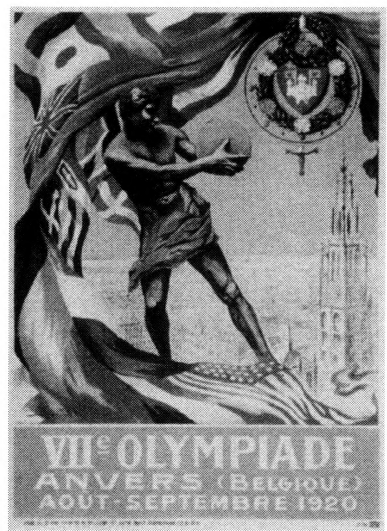

Figura 6 


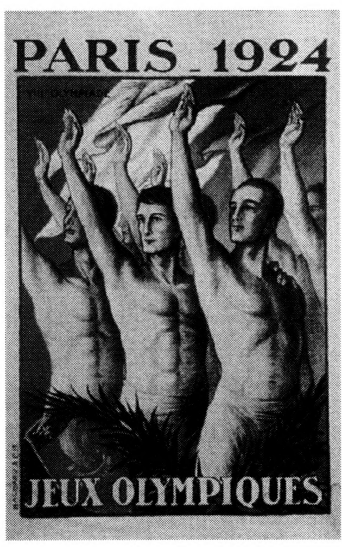

Figura 7

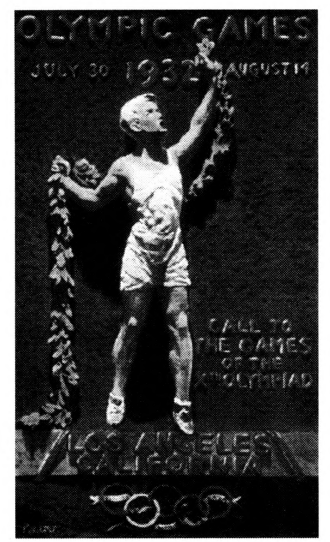

Figura 9

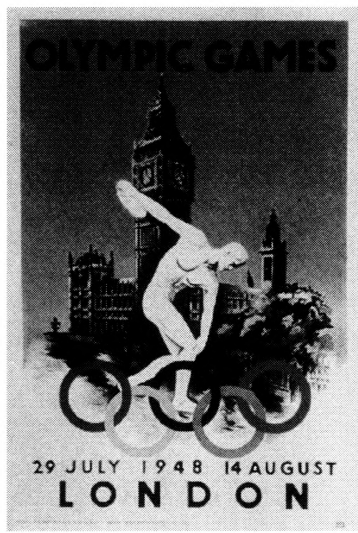

Figura II

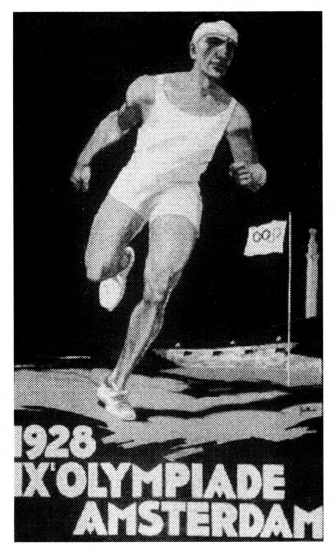

Figura 8

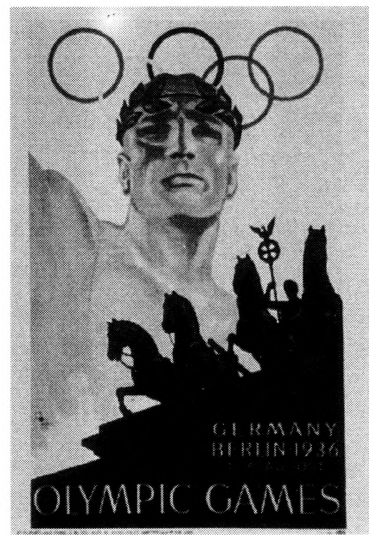

Figura 10

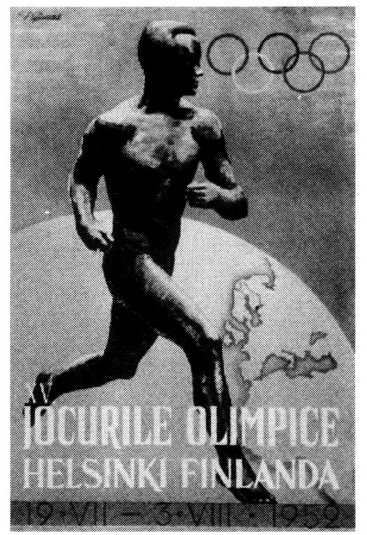

Figura 12 


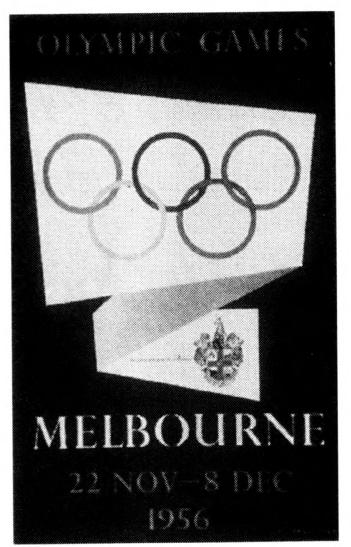

Figura 13

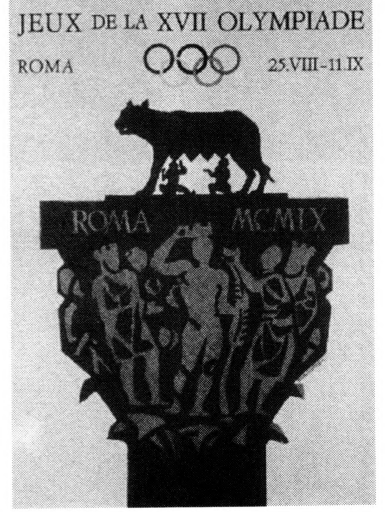

Figura 15

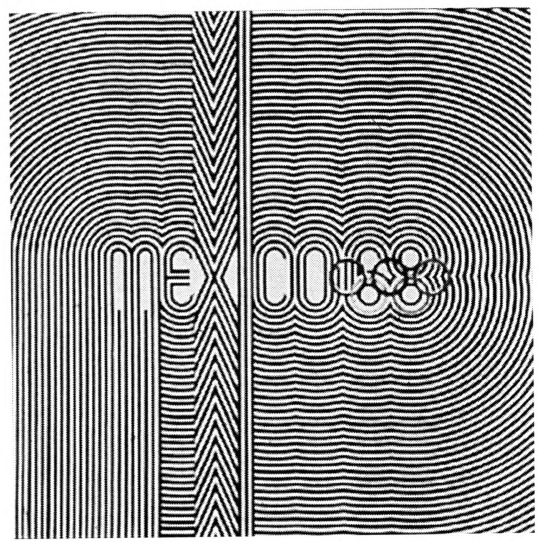

Figura 17

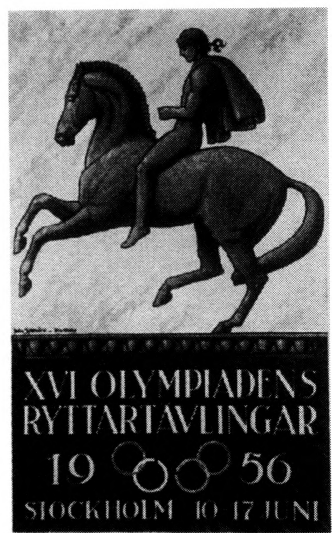

Figura 14

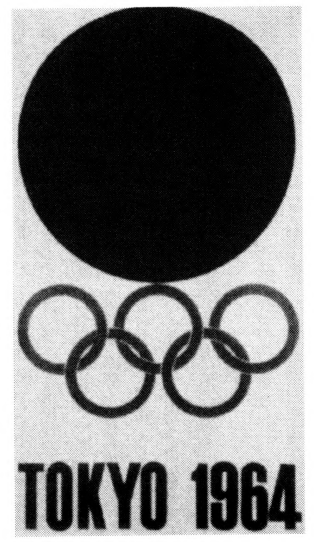

Figura 16

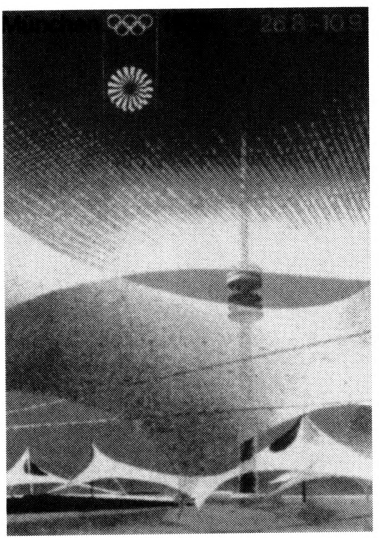

Figura 18 


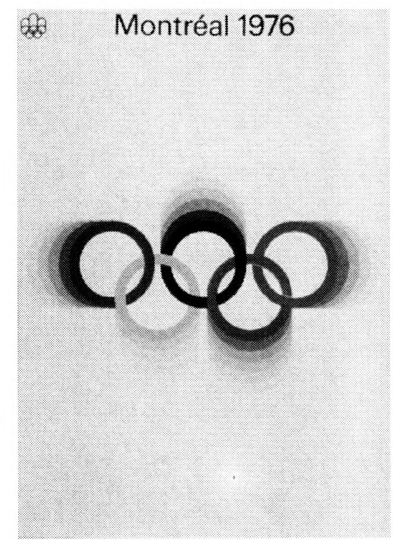

Figura 19

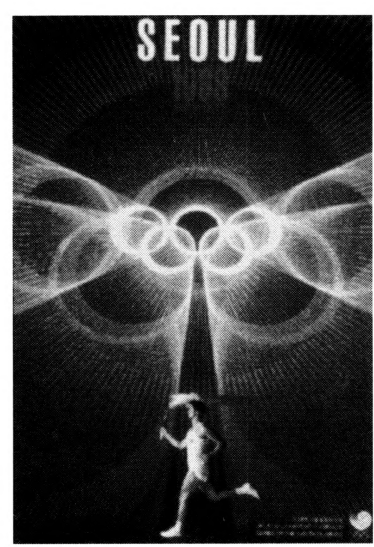

Figura 21

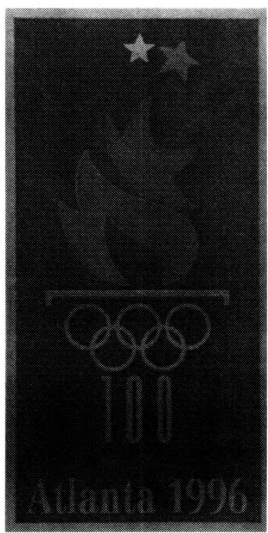

Figura 23

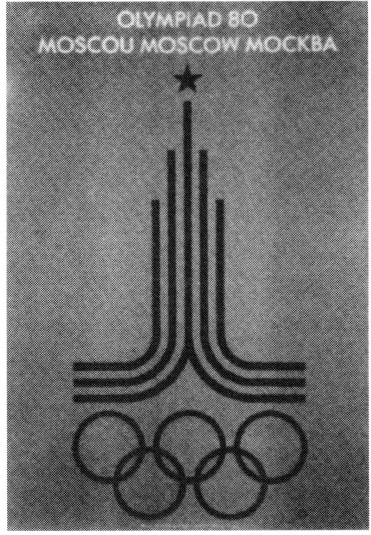

Figura 20

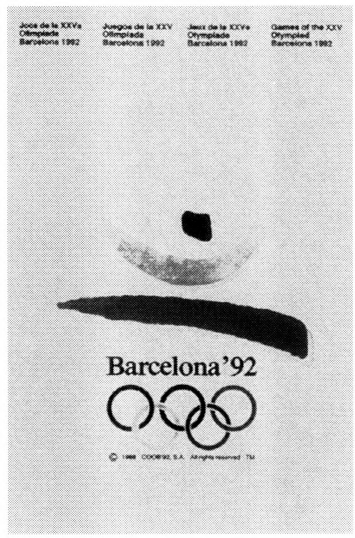

Figura 22

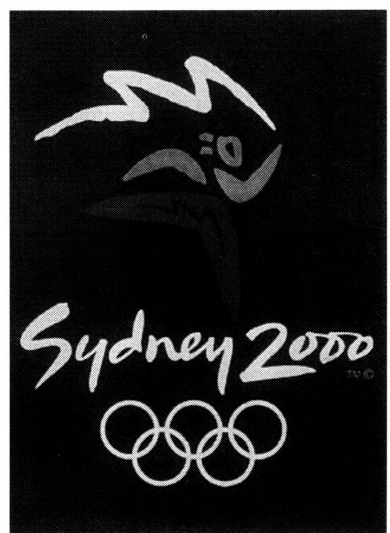

Figura 24 